\title{
The Impact of Human Resource Management Practices, Organisational Culture, Organisational Innovation and Knowledge Management on Organisational Performance in Large Saudi Organisations: Structural Equation Modeling With Conceptual Framework
}

\author{
Sami Abdullah Al-bahussin ${ }^{1} \&$ Wael Hassan El-garaihy ${ }^{2}$ \\ ${ }^{1}$ Department of Business Administration, College of Business Administration University of Dammam, Saudi \\ Arabia \\ ${ }^{2}$ Department of Business Administration, College of Applied Studies and Community Service, University of \\ Dammam, Saudi Arabia \& Seconded by University of Port Said, Egypt \\ Correspondence: Wael Hassan El-garaihy, College of Applied Studies and Community Service, University of \\ Dammam, Saudi Arabia. Tel: 966-568-275-441. E-mail: whgaraihy@ud.edu.sa
}

Received: August 19, 2013

doi:10.5539/ijbm.v8n22p1
Accepted: October 8, $2013 \quad$ Online Published: October 15, 2013

URL: http://dx.doi.org/10.5539/ijbm.v8n22p1

\begin{abstract}
The conceptes of human resource management practices, organisational culture, knowledge management, organisational innovation, and organisational performance in the human resource management research field have been implemented. Although the results of literature were significant, no studies were released in order to conduct a study about the function of human resource management practices in intensifying the organisational performance with interfering organisational culture, knowledge management, and organisational innovation. The purpose of this study is to narrow this gap in the research. The study, moreover, attempts to investigate the connections amid organisational culture, knowledge management, and organisational innovation. The research utilizes causality models and suggests a conceptual schema subsequent to a comprehensive analysis of the literature linked to human resource management field. A sample of 203 human resource directors working in large organisations in the Eastern Region of Saudi Arabia is used. The confirmatory factor analysis [CFA] and SEM are used to analyze and approve the proposal of the conceptual schema.

The study illustrates that human resource management practices is an important ancestor of organisational culture, knowledge management, and organisational innovation, which have in turn a positive link to organisational performance. The research attempts to draw concentration to some of the elements, playing the function of arbitrator amid human resource management practices and organisational performance. The study is unique because it is initially conducted to urge the impacts of some important related patterns such as human resource management practices, organisational culture, knowledge management and organisational innovation, and organisational performance.
\end{abstract}

Keywords: human resource management practices, organisational culture, knowledge management, organisational innovation, organisational performance and large Saudi organisations

\section{Introduction}

Human resources must be seen as the most important wealth, which must be maintained by any organisation. This issue is very important, especially when the organisation seeks to create a successful and effective knowledge management environment in order to help it develop its resources in the appropriate place and the correct time, especially for knowledge professionals who are characterized by their multiple cultures and multi nationalities, attitudes and opinions (Lord \& Farrirgton, 2006). Knowledge management aims at seeking to innovation and successful acquisition of knowledge in the operations of management, impacting the organisational innovation. 
Organisational culture is the most effective path for knowledge management and organisational innovation as the role of organisational culture is to determine the values and beliefs and work systems that can encourage or hinder both processes of knowledge creation and of knowledge sharing (Alavi \& leidner, 2001; Gold, Malhotra, \& Segars, 2001). Organisational culture also leads to change and organisational innovation (Lynn, 1999).

Exploring the effect of human resource management practices on the organisational performance, and investigating the role of intermediate variables among them, and also analyzing the relationships among these mediator variables are significant issue. This may help in presenting a proposal of an integrated model to explore and analyze those relationships in the large Saudi organisations, through creating a conceptual framework that contributes in studying and embodying those relationships. Saudi Arabia and other Gulf countries rely on a very large proportion of non-national workers who are chosen according to their skills, and replacing them will be often relatively inexpensive for organisations. Therefore, organisation may not possess any motivations to improve proficiencies directly by learning and development activities. Organisations working in the region consider investments in human resources management practices may not be effectively economic.

The current study seeks through experience and analysis to provide a new compound model in order to explore the influence of distinct human resource management practices on the organisational performance. It also seeks in order to investigate the role of mediator variables between them, and what are the relationships among these variables. It can then be proposed a model help to explore and analyze the relationship in the large organisations in Saudi Arabia. Identifying the component of each of (organisational culture, organisational innovation and knowledge management), the current study aims to respond the following queries:

- Can organisational performance in large Saudi organisations be improved through the practices characterized human resource management? And To what extent do these practices have influence on the organisational performance?

- Do the mediator variables play a crucial role amid human resource management and organisational performance in improving the organisational performance?

\section{Research Constructs}

This part of study examines the literature to determine the closely related practices constituting Human resource management, Organisational culture, Knowledge management, organisational innovation, and Organisational performance.

\subsection{Human Resource Management}

As competition is technologically, economicly, and demographicly imposed on organisations to be developed, they have to take into consideration human resources as priceless economic resources and confront stress through using Human Resource Mmanagement more efficiently (Tichy, Fombrun, \& Deyanna, 1982; Khatri, Wells, McKune, \& Brewer, 2006). For example, HRM is the process which involves recruiting individuals into the organisation to execute a definite duty such as monitoring performance, and giving compensations to adhere the productivity of individuals Tichy et al. (1982). Researcher considers four dimensions of human resource, involving collection, evaluation, compensation, and evolution.

There are five major dimensions related to competitive strategies as human scheming options, recruiting options, evaluation options, rewards options, and learning and development Schuler and Jackson (1987). Gupt and Singhal (1993) interpreted conceptually Human Resource Management practices to four dimensions, involving human resource scheming, effeicency assessment, compensation patterns and profession superintendence. The functions of HRM are categorized by Gomez-Mejia, Balkin, and Cardy, (1998) into nine dimensions including workflow, recruiting, managing dismissal, proficiency assessment, learning and development, compensation management, relationships amid employees, empowerment and internationalization.

\subsection{Organisational Culture}

Organisational culture is an ambiguous term because there is no single definition mostly approved by each of literatures of organisational culture. The problem in giving a clear definition of culture is that it gives a definition of both its actions and reactions (Shili, 2008). Organisational culture is defined as a complicated connection of values and standards, leading one's attitudes. It includes a group of thoughts, values, expectations and experience gained through eduaction, socialization and participation of social unit employees such as staff in the organisation (Rousseau, 1990). Nearly all the interpretations of culture confirm the organisational hypothesis matured, fostered and guided either intentionally or unintentionally over the lifelong of organisation. These aspects comprises experiences, standards, values, philosophy and formal procedures that consolidate the organisation, its picture, self-image, internal operations, cooperation with the external surroundings where some 
of the values are saved in either written or unwritten shape; however, they are severely committed to (Schein, 1984).

Organisational culture is obvious to be a process that the organisational creators, senior management and staffs training, socialize and adapt over time (Schein, 1984). It picks out the most desirable culture suiting the organisation's goals and being effortlessly approved by broader surroundings (Robbins \& Judge, 2009). Alvesson and Berg (1992) suggest that organisational culture is a management instrument used to help in rationalizable effort and efficient conceiving: an endeavor to improve rule practices neither established upon constrain nor on guidance. Workers struggle to have the authority over themselves or each other (Parker, 2000). The main function of director is to create a culture and its manipulation. Parker (2000) also suggests that the strength of cultural hypothesis is specifically observed in areas in which direct control and instruction practices are not easily or possibly maintained.

\subsection{Knowledge Management}

Knowledge management is a business process established by companies to utilize their institutional or collective knowledge (Sarvary, 1999). It comprises three sub-procedures: organisational learning, knowledge manufacture, and knowledge arrangement. Numerous different attempts, in the area of Knowledge Management, have been conducted to categorize and clarify knowledge and associated expressions in the past, which are still arguable. When concentrating on knowledge management, the debates of literature are frequently concerned about the qualities of knowledge, the dissimilarity between information of knowledge and calssification of knowledge. The literature, however, includes several various study practices and viewpoint. Irma \& Rajiv (2001) defined knowledge as justified true belief while Kucza (2001) defined it as "information in action", like the requirements of applying information. Knowledge was explained as substantiated personal belief increasing people's ability to act effectively which represents a very appropriate definition, and can be applied in any fields (Nonaka, 1994)

A definition of the efficient knowledge management produced by Irma and Rajiv, (2001) demonstrated that it is a significant factor to achieve the accomplishment of modern organisations, which could be significantly varied in their willingness for successful inaugurate and development of knowledge management initiatives. The successfulness and unsuccessfulness of knowledge management in an organisation, depends on identifying and estimating prerequisites that are essential for the attempt to succeed. Gold et al., (2001) described these prerequisites as capacities or resources available in the literature of organisational behavior. Although the previously mentioned efforts and other ones that demonstrate knowledge management have been pledged, only have they always handled great level of procedures, specialized on specific aspects, or handled so broad knowledge management that it is difficult to be determined due to its nature and complexity. Both organisations and knowledge systems comprise of four groups of social legislation "knowledge practices": establishment, storage/retrieval, transfer, and application (Alavi \& Leidner, 2001).

\subsection{Organisational Innovation}

Many definitions of innovation have been provided by authors, such as the definition given by Roger (1995) that innovation is the creation of modern thoughts or practices. Freeman and Soete (1997) defined innovation as the new products or process first launched in the market. Innovation can be categorized according to several classifications based on the definition and standards used. According to producing results, for instance, it will be classified as product innovation, process innovation, and service innovation, and according to the level of alterations, it will be classified as the radical innovation and incremental innovation. Four major categories, according to Avermaete, Viaene, Morgam \& Crawford (2003), have been used to determined innovation as follow: Product innovation, Process innovation, Market innovation and Organisational innovation.

Innovation can strengthen incorporated performance, including: profitability and sales growth (Hsueh and Tu, 2004). The organisation should, accordingly, concentrate on the decision-makers' ability, technology, resources, and positive work environment to enhance innovation in firms (Chalhoub, 2010; Craig \& Dibrell, 2006). Nevertheless, Francis and Bessant (2005) indicated the organisations should take into consideration those different kinds of innovation need different management and resources because this will have an effect on the innovative ability.

\subsection{Organisational Performance}

Several researches have been conducted various methods to evaluate organisational performance (Wong \& Wong, 2007; Prajogo, 2007; Moneva, Rivera-Lirio, \& Muñz-Torres, 2007). Steer (1975) conducted a general study on 17 patterns of organisational productivity and merged the components of these different researches relating to the evaluation of organisational performance. Organisational performance is a sign of the capacity of 
a company to efficiently achieve independent goals (Venkatraman \& Ramanujam, 1986). After examining ten various kinds of assessments, they made the findings general into three aspects: financial performance, business performance and effective organisation. A system was developed by Delaney and Huselid (1996), involving two elements for estimating market performance: market share and earnings ratio. Moreover, a fully completed set of dimensions for human resource performance has been suggested by Huselid, Jackson, and Schuler (1997).

Lee and Lee (2007) discovered that organisational performance estimates the strong effect of the managers and employees' behavior. Thus, the methods of organisational performance assessment in Knowledge Management can be classified into four categories: commercial measurements, intellectual capital, tangible and intangible profits, and a balance scorecard. Hanvanich, Sivakumar, Tomas, and Hult (2006) improved an organizational performance measure pattern that integrates firm's comprehensive performance and creativity to evaluate the comprehensive organisational performance.

\section{Conceptual Framework}

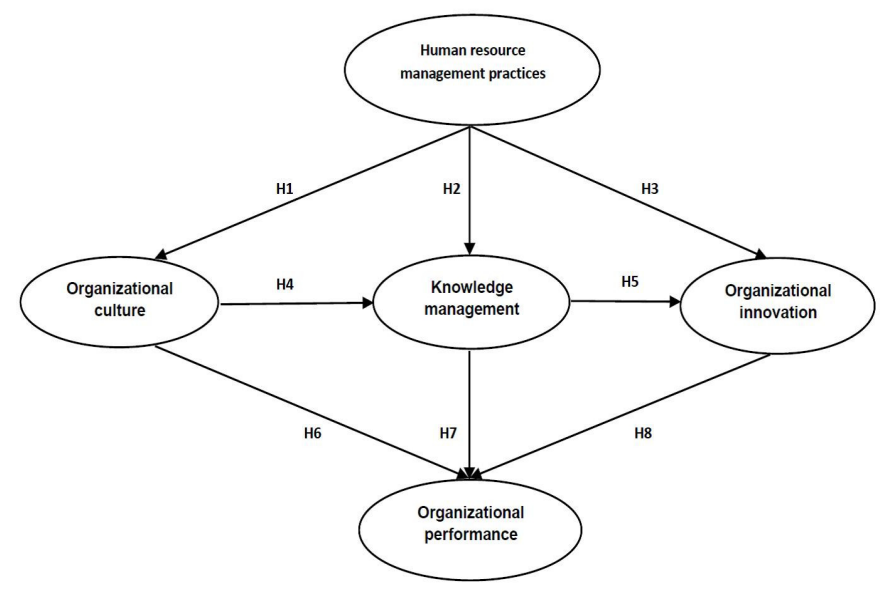

Figure 1. Research conceptual framework

Figure 1 demonstrates the conceptual framework of human resource management practices relationship with organisational performance and indicates that human resource management practices positively relate to organisational culture, organisational innovation, and knowledge management. Each of them is successively associated to organisational performance. Organisational culture has also a positive relation to organisational innovation that successively has a relation to knowledge management. Figure 1 shows the hypothesized pattern with a tacit assumption indicating that the impact of human resource management practices on organisational performance is mediated by organisational culture, organisational innovation and knowledge management.

\subsection{Human Resource Management and Organisational Culture}

HRM and organisational culture are complexly related. Buchowicz, 1990; Denison, 1990; Calori and Sarnin, 1991; Check-Teck, 1992; Cawood, 2008 indicated that literature about organisational culture owns primarily affirmed its effect on organisational effectiveness. Complexity escalates as arguments on definition and main goal continue to develop in both fields (Gomez \& Rodriguez, 2001; Rodriguez, 2001). Schultz (1994) indicated that a significant argument debates how organisational culture functions in the shape of common definitions which may be noted at various levels; from the more visibly identifiable ones, such as artifacts and innovations; to more imperceptible ones such as hypothesis and philosophies.

Brewster (2007) indicated that the concept of cultural sound and context-bound practices turned into being essential to argue on Universalist in contrast to contextual models in Human Resourse Management. This indicated changing from standard general Human Resource Management patterns regarding a more comprehensive contemplated method where context is critical to decide the best method to "achieve" Human Resource Management. Buono (2005), Bunch (2007), and Taylor, Levy, Boyacigiller, and Beechler, (2008) have researched this relationship through studying its effect on. This study, in agreement with the studies demonstrated above, presents a proposal for the following thesis:

H1. HRM has a positive effect on organisational culture. 


\subsection{HRM and Knowledge Management}

The significance of human resource in carrying out Knowledge Management in addition to the proof that individuals' problems require to alter to middle phase in considering knowledge (Yahya \& Goh, 2002; Thite, 2004; Gloet, 2006). Several authors such as Scarbrough and Carter (2000), Robertson and Hammersley, (2000) take into consideration best human resource management practices to develop the basic elements of KM success.

Soliman and Spooner (2000) suggested that human resource management practices have a significant part in promoting staffs' well understanding, transfer, exchange and establishment of knowledge. Scarbrough (2003) correspondingly specified that human resource management practices, as alternative approaches, recompense plans and working systems, appear to "own an effect on the progress of knowledge where Knowledge Management pursuits maximization". Oltra (2005) argued that individual humans are the final knowledge establishers and massengers. Therefore, increasing their capabilities as organisational knowledge supporters is the principle purpose. The strict and strategical management of individuals must behave as a motivation towards productive procedures of ultimate advantage of knowledge. The second thesis, therefore, has a definition as follows:

\section{H2. HRM has a positive effect on knowledge management.}

\subsection{HRM and Innovation}

Human resource management practices have an effect on staffs' learning and behavioral changes. The basic role of HRM is to get talented individuals who own the essential skills, proficiency, and readiness to work with joint-ventures. Furthermore, the compensation system has an important part in motivating employee to develop work which enables employees to take part in the organisation (Hewitt-dundas, 2006). Several experts have the same viewpoint indicating that human resource management has an effect on innovation and firm performance. There is evidence, resulted from the academic literature review, indicating a relationship between human resource management and innovation. Jiménez-Jiménez \& Valle (2005) clarifies this relationship suggesting that the company using innovative strategies sought to hire staff from the outside, and was interested in training, rewards, participation, performance evaluation, and internal career opportunity. Yuan Li, Yongbin Zhao and Yi Liu (2006) conclude the results: (1) Human resource management had an effect on innovative technology and caused top incorporated performance. (2) Training had a direct effect on technological innovation. (3) Material incentives had a negative relationship with technological innovation. (4) Non-material incentives had a positive relationship with technological innovation. Ling and Nasurdin (2010) suggest that the (1) Training had a direct relation with innovative product, innovative procedure, and innovative administration. (2) Performance evaluation had an effect on administrative innovation. Eventually, Strategic human resource management had a direct effect on technology innovation and indirect through knowledge management (Chen \& Huang, 2009). This study, in agreement with the studies demonstrated above, presents a proposal for the following thesis:

H3. Human resource management has a positive effect on organisational innovation.

\subsection{Organisational Culture and Knowledge Management}

Cultural change is extremely difficult, wasteful time, and frustrating organisational process. Chances of development are low especially when the culture change goal is not recognized or approved by employees. Change can be promoted through a strong awareness campaign. Schein (2000) also indicates that it is more efficient to empower cultural evolution than to drastic implementation of fundamental change. McDermott and O'Dell (2000) assumed that it is an effective method to straighten the knowledge management system with the organisational climate rather than to try to alter its culture.

Both researchers and professionals completely agree that a knowledge-sharing supportive organisational culture has to be displayed or cared for in organisations for knowledge management initiatives to achieve development. Nevertheless, as mentioned previously, not many academic researches have been conducted to identify the basic organisational culture characteristics that support more effective use of knowledge management technologies and knowledge distribution. This study, in agreement with the studies demonstrated above, presents a proposal for the following thesis:

H4. Organisational culture positively affects knowledge management.

\subsection{Knowledge Management and Organisational Innovation}

Knowledge management ability has a definition that the capability of corporations in the possession, alteration, and implementation of knowledge. Knowledge would not be capable of developing innovation provided that it 
cannot be apportioned or allocated to the related individuals. Carrillo, Robinson, Ahmed, and Anumba, (2004) indicates that corporations have the ability to utilize knowledge inside the organisation through information technology supportive aid such as intranet, information systems, or non-information technology means such as brainstorming meetings and research cooperation. Corporations can, therefore, enlarge innovation by the implementation of knowledge. Through changing procedure, corporations can distribute, incorporate, and develop innovation performance by converting tacit knowledge to systematized or explicit knowledge. Thus, corporations have the ability to develop their Knowledge management capability and establish more innovation. The next thesis is accomplished based on the forementioned:

H5. Knowledge management will significantly impact organisational innovation.

\subsection{Organisational Culture and Organisational Performance}

The management of literature has generally approved the idea that the organisational culture has a positive relation with organisational Performance; however, it is still an emerging research field and the experimental data is still somewhat seldom. A top level of organisational performance is generally linked to an organisation, possessing an effective culture with appropriately merged and productive set of values, opinions and attitudes (Denison, 1990; Kotter \& Heskett, 1992). Economic hypotheses indicate that a corporation's organisational culture issues are very significant for its policy options. Majority of leading companies now realize new ways enable them to evaluate their intangible properties, staffs having a true "live" the company's cultural values. Several authors reported that culture would continue related to greater performance in case that the culture can conform to alterations in conditions of environment. Moreover, Lim (1995) indicated that Not only must the culture be widely distributed, but also it has to possess unequaled characteristics that cannot be duplicated. Criticism has been done to the relation amid cultural strength and organisational performance due to its simplification and somewhat prescriptive approach to the cultural management. Research examined the effect of cultural strength on organisations' economic performance indicates only a modest positive association (Siehl \& Martin, 1990). One reason may be that a strong controlling culture performs through putting down suitable subcultures, restricting the articulation of other values which could sustain the organisation manage change.The following thesis is developed based on the forementioned:

H6. Organisational Culture significantly affects organisational Performance.

\subsection{Knowledge Management and Organisational Performance}

The disparities in Knowledge management activities of firms that build structure in order to analyze corporate knowledge requirements indicated that firm performance is considerably affected by these management gaps (Lin \& Tseng, 2005). Statistical significance in relations among KM, procedures, and performance after conducting a research to analyze hypothesized structural relationships with the collected data is concluded by Lee and Lee (2007). Three factors of Knowledge management systems, reported by Bogner and Bansal (2007), affect company performance: the company's capability to present new knowledge, its capability to construct on that knowledge, and its efficiency in seizing a great ratio of following corporate spin-off. Based on the studies debated above, the following hypothesis is adopted:

H7. Knowledge management positively influences organisational performance

\subsection{Organisational Innovation and Organisational Performance}

Several studies emphasize that organisational innovation positively affects performance, and suggest that innovation can cause grater organisational performance in any fields it deals with. This result has been approved in several types of manufactures, such as public utilities (Damanpour \& Evan, 1984), service (Subramanian \& Nilakanta, 1996) and advanced technology projects in Taiwan (Lin, 2001). Demanpour (1991) drew the attention to some findings on the new theory of organisational innovation while majority researchers confirmed and adopted the point of view of double centre pattern. This opinion suggested that innovation involves innovative administration and technical innovation. Furthermore, Damanpour and Evan (1984) conducted a test on the effect of these two kinds of innovation on organisational performance. The two kinds of innovation affect each other and have integrated effect on performance. Based on these researches illustrated above, the following hypothesis is adopted:

H8: organisational innovation positively affects organisational performance.

\section{Data Collection}

Collected Data aimed at studying the impacts of human resource management practices, organisational culture, organisational innovation, and knowledge management on organisational performance through direct surveys 
via mail to the human resources departments' officials in the large Saudi organisations under study. The Gulf region are thought to be one of the most developed areas in the world where the development rate estimated by $20 \%$ annually (De Bcer and Turner 2007; Mellahi et al., 2001). Unctad Org. (2013) identified the amount of foreign investment in the region has increased from less than $\$ 2$ billion in (2001) to more than $\$ 60$ billion in 2013. Although this region is economically important, there are very few studies that have attracted the scholars' attention to that region.

The population study includes all large Saudi organisations recorded in Chamber of Commerce and Industry in the Eastern Province on 12/01/2013. The number of these organisations is (88). The names of organisations were obtained from a list of the Department of associates that belongs to Chamber of Commerce and Industry in the Eastern Province. 3 Questionnaires have been distributed for those working in human resources management in each organisation. Thus, the total number of questionnaires distributed was 264 Questionnaires. The number of approved questionnaires was (217), representing (82.2\%) of the total number of questionnaires distributed. the study is limited on human resources management officials, whether they hold Saudi nationality or non-Saudi nationalities. Al-Kibsi, Benkert, and Schubert (2007) reported that the estimations of unemployment in the Gulf region among the local population ranges between 10 to 15 percent.

\section{Procedures}

Based on a comprehensive survey of the literature and interpretations utilized in this research, both researches developed a set of procedures to be used in the survey. Human resource management practices, organisational culture, organisational innovation, knowledge management, and organisational performance, consistent with previous researches, were calculated according to seven points of Likert scales, with anchors of $1=$ strongly disagree and $7=$ strongly agree. The survey, therefore, is composed of five parts including the previously mentioned variables (see apendex A).

Human resource management practices differed connected to the performance, according to many studies related to this side. Wiesner and McDonald (2001); Bowen, Galang, and Pillai (2002); Guest, Michie, Conway, and Sheeman, (2003); Michie and Sheehan (2005); De Kok, Uhlaner, and Thurik (2006); Sels et al. (2006) have, therefore, adopted the results of several previous studies in this field. On the basis of a survey of those studies, the most consistent elements and commonly used have been selected in these studies to clarify the human resource management practices, which included fourteen factors, such as: employees' safety, selective recruiting, teamwork, incentives and performance-based rewards, training, employee engagement, interior job opportunities, job duties, alignment and health and safety policies.

Zack (1999); Chang Lee, and Kang, (2005); Shih and Chiang (2005) have conducted several studies on knowledge management, which indicated that the most consistent elements, and commonly used in these studies have been chosen to illustrate the structure of knowledge management, which included five items.

The study also adopted what came in the Subrmanian and Nillatanta's (1996) of measure of the dimensions of organisational innovation. Based on this study, five elements corresponding with the nature of the population study have been adopted. The study also adopted, regarding the organisational culture, the policies included in the study of Wallach (1983), in which three dimensions of the culture of bureaucracy, the culture of innovation, and the culture of support have been adopted. Those elements, consequently, have been filtered until choosing five elements representing constructing organisational innovation.

Organisational performance is shared to two sets of measurements, financial measurements and non-financial measurements. According to Nielsen (2006), financial performance has been measured as a two-dimensional measure. These two dimensions represent the company's profitability, market performance, and finally, the non-financial measure. The seven factors represent constructing organisational performance. According to those factors, the directors of human resources management are asked to determine the performance of their own organisations compared with competitors.

After that, initial list has been displayed. It included 36 items enclosing five constructs in the field of human resources management from the same research community, who have thoroughly reviewed and asked to delete some items. The same situation was repeated with two professors from the Division of Human Resources at the University of Dammam, who deleted some of the factors. Thus, the final number becomes 28 factors including ( 8 items of human resources management, 5 items of organisational culture, 5 items of knowledge management, 4 items to construct innovation, and 6 items to construct organisational performance). These items included in the list of the survey have been sent to the human resources management officials of organisations under study. 


\subsection{Pilot Testing and Questionnaire Administration}

20 experimental tests were entirely conducted with the managers of human resource management department who were observed corresponding to the research sample. The pre-test aimed to filter the questionnaire and to evaluate the validity and suitability of measurements of the service sector. Analogous modifications have been done to the questionnaire after conducting the experimental tests. 264 questionnaires were entirely shared among large organisations working in the Eastern Province of Saudi Arabia. The procedure resulted in 217 completed questionnaires with a response rate of 82.2 percent. 14 of the entire questionnaires were incomplete, resulting in a total of 203 applicable questionnaires. Out of the 203 applicable questionnaires, 123, representing 60.59 percent, indicated that the organisations' experience in human resource departments ranged between one to five years. 80 questionnaires, representing 39.41 percent, indicated that their experience in human resource departments was more than five years. These results indicate that the participants had sufficient knowledge with the human resource departments. The age of sample is basically ranged between 41-60 (66 percent) with an additional 34 percent whose age ranged between 24 and 40 . The highly educated participants represented 68 percent.

\subsection{Data Analysis and Findings (Results)}

\subsubsection{Factor Analysis and Scale Reliabilities}

Byrne (2001) carried out a confirmatory factor analysis (CFA) by using Amos 7.0 to test the validity of measures used in the study. The use of the confirmatory factor analysis over the exploratory factor analysis has been recommended by Byrne, (2001) due to its basis on a theory explaining measurement error, and testing for unidimensional model. To reach the last group of items for each construct, researchers eliminated 13 itemes from the first set of 28 itemes established upon item-total correlations and the standardized remaining values (Byrne, 2001; Rokkan, Heide \& Wathne, 2003). The eliminated itemes were tested and assimilated to original conceptual definitions of the constructs. In each case, eliminating the constructs did not have any significant changes on the field of the construct as it was primarily conceptualized. The concluding joint of items was therefore under the influence of confirmatory factor analysis. A completely standardized solution resulted from Amos 7.0 that uses maximum probability estimation demonstrated that all remaining 15 items burdened extremely on their analogous factors that confirm the unidimensionality of the constructs and supplied effective experimental proof of their validity. The t-values of the loadings were high, indicating sufficient convergent validity. The resulting measurement model was $\mathrm{x}^{2} 203=168.694 ; \mathrm{p}=0.000$; Goodness of Fit Index (GFI) $=$ 0.91; Adjusted Goodness-of-Fit Index $(\mathrm{AGFI})=0.86$; Comparative-Fit-Index $(\mathrm{CFI})=0.95$; Incremental Fit Index $($ IFI) $=0.96$; Root Mean Square Error of Approximation $($ RMSEA) $=0.07$, indicating a positive adaptation. The measurement model and the standardized loadings together with critical ratios are demonstrated in Table 1. Byrne, 2001; Hair et al., 1998), based on the previous literature, indicated that the choice of determining the definite items was merely arbitrary. Cronbach alpha coefficients were then calculated to figure out the two factors of the reliability scale identified and were 0.86 (human resource management practices), 0.83 (organisational culture), 0.92 (knowledge management), 0.79 (organisational innovation) and 0.91 (organisational performance). Therefore, reliabilities ranged from 0.79 to 0.92 , supplying further support to confirm that all the scales used in this research characterized with acceptability and reliability (Nunnally, 1978). The intercorrelations, means, and standard deviations of the five constructs used in the research are illustrated in Table 2. 
Table 1. The measurement model

\begin{tabular}{ll}
\hline & Constructs \\
\hline Human resource management practices &
\end{tabular}

HRM7- Employees are related to reward system based on the team's performance or the performance of the

$\begin{array}{llll}\text { SCR } & \text { VE } & \text { SL } & \text { (CR) }\end{array}$

$0.86 \quad 0.71$

group, connecting with a part of the salary to performance.

HRM9- There are opportunities for those workers in this organisation to attend training courses to improve

or learning new and multiple skills.

HRM12- Employees have clear career paths and potential opportunities for promotion within the organisation.

\section{Organisational culture}

OC1 - The culture of the organisation depends on the division of authority sequence. There are also clear lines of responsibility and authority.

OC2- Working in the organisation is considered structured and systematic. Culture of the organisation is usually based on control and power.

OC3- Organisation working environment is to be perfectly suited for innovation and leadership, adventure, challenge, creativeness, and results-oriented.

\section{Knowledge management}

KM2- Employees regularly attend courses and seminars and training programs in order to be permanently updated with new knowledge.

KM3- The experience owned by organisation's experts is adopted to contribute to and participate with others within the organisation.

KM4- The workers of organisation shall inform each other regularly on the positive experiences and successful working methods.

\section{Organisational innovation}

OI2- The organisation spends a lot of time for the production of useful and developed ideas in the field of services.

OI3- The organisation has, during the past five years, developed and implemented many of the modern management methods.

OI5- We get a lot of support from our managers if we want to try new ways of doing things.

\section{Organisational performance}

OP2- Net profit.

Notes: $\mathrm{SCR}=($ Scale composite reliability $), \mathrm{VE}=($ Variance extracted $), \mathrm{SL}=($ Standardized loadings $), \mathrm{CR}=($ Critical ratio $)$.

Table 2. Construct inter-correlation matrix

\begin{tabular}{lccccc}
\hline \multicolumn{1}{c}{ Constructs } & $\begin{array}{c}\text { Human } \\
\text { resource } \\
\text { management } \\
\text { practices }\end{array}$ & $\begin{array}{c}\text { Organisational } \\
\text { culture }\end{array}$ & $\begin{array}{c}\text { Knowledge } \\
\text { management }\end{array}$ & $\begin{array}{c}\text { Organisational } \\
\text { innovation }\end{array}$ & $\begin{array}{c}\text { Organisational } \\
\text { performance }\end{array}$ \\
\hline Human resource management practices & 1.0 & & & & \\
Organisational culture & 0.54 & 1.0 & 1.0 & & \\
Knowledge management & 0.55 & 0.69 & 0.54 & 1.0 & 1.0 \\
Organisational innovation & 0.69 & 0.51 & 0.70 & 0.60 & 5.23 \\
Organisational performance & 0.53 & 0.73 & 5.32 & 5.35 & 1.31 \\
Mean & 4.95 & 5.38 & 1.25 & 1.40 & \\
Standard deviation & 1.42 & 1.30 & 1.35 & \\
\hline
\end{tabular}

Notes: The inter-correlations, means, and standard deviations of the five constructs used in the study are reported in Table 2. 


\subsubsection{Hypothesized Model}

Structural equation modeling was utilized to evaluate parameters of the hypothesized model, which identified human resource management practices as an exogenous construct. The human resource management practices had a selective relationship with the mediating constructs of organisational culture, knowledge management and organisational innovation each of which was therefore linked to the internal construct (organisational performance). Organisational culture was also related to knowledge management that successively was linked to organisational innovation. The goodness of fit of statistical models indicates the comprehensive reliability of the hypothesized model analyzed, were acceptable: $\mathrm{x}^{2} 203=168.82 ; \mathrm{p}=0.000$; degrees of freedom $=82$; GFI $=$ $0.91 ; \mathrm{AGFI}=0.87$; CFI $=0.96$; IFI $=0.96$; RMSEA $=0.07$. The SEM results are shown in Table 3. Researchers assume, according to Anderson and Gerbing (1988) that convergent validity becomes available when the critical ration (CR) of the variables studied versus their corresponding latent variables is over 1.96 at the 0.05 level. Fornell and Larker (1981) illustrated in Table 1 that the scale composite credibility and the average varience extracted for each construct was quite acceptable. The composite reliability, which is an internal consistency credibility measure as further proof of convergent validity computed from Amos solutions, ranged from 0.84 to 0.95. Hair, J. F. Jr., Anderson, R. E., Tatham, R. L., \& Black, W. C. (1998) emphasized that the average variance extracted for each construct ranged from 0.64 to 0.86 , which exceed the acceptable level of 0.50 . It can be noted from Table 3, that all the critical ratios of the indicators of constructs fulfill this standard, so the convergent validity of the measurements is illustrated and the recomended relationships between indicators and constructs are approved. As hypothesized, human resource management practices had a significant and positive relationship with organisational culture (parameter estimate $=0.533$, t-value $=6.593$ ); knowledge management (parameter estimation $=0.246, \mathrm{t}$-value $=3.438$ ) and organisational innovation (parameter estimation $=0.552$, $\mathrm{t}$-value $=6.854$ ). Thus, $\mathrm{H} 1, \mathrm{H} 2$ and $\mathrm{H} 3$ are all approved. Also, as hypothesized, organisational culture had a significant relationship with knowledge management (parameter estimation $=0.548$, $\mathrm{t}$-value $=6.722$ ) that was successively linked to organisational innovation (parameter estimation $=0.236$, t-value $=3.190$ ). Therefore, $\mathrm{H} 4$ and H5 are also approved. Eventually, organisational culture (parameter estimation $=0.415$, t-value $=5.255$ ), knowledge management (parameter estimate $=0.285, \mathrm{t}$-value $=3.750$ ) and organisational innovation (parameter estimation $=0.231$, t-value $=3.650$ ) were each related to the organisational performance. Thus, H6, H7 and H8 are also approved.

Table 3. Structural model estimates

\begin{tabular}{|c|c|c|c|c|c|c|}
\hline & ELATION & Estimates & $\begin{array}{c}\text { Standard } \\
\text { error }\end{array}$ & $\begin{array}{c}\text { Critical } \\
\text { ratio } \\
\end{array}$ & $\mathrm{P}<$ & $\begin{array}{c}\text { Standardized } \\
\text { estimates }\end{array}$ \\
\hline Organis & sational culture & 0.452 & 0.068 & 6.593 & 0.000 & 0.533 \\
\hline$\longrightarrow$ & ledge management & 0.223 & 0.064 & 3.438 & 0.000 & 0.246 \\
\hline $\mathrm{HRP} \longrightarrow \quad$ Organi & isational innovation & 0.564 & 0.081 & 6.854 & 0.000 & 0.552 \\
\hline Organisational culture & $\longrightarrow$ Knowledge management & 0.585 & 0.086 & 6.722 & 0.000 & 0.548 \\
\hline Knowledge management & $\longrightarrow$ Organisational innovation & 0.459 & 0.087 & 5.255 & 0.000 & 0.415 \\
\hline Organisational culture & $\longrightarrow$ Organisational performance & 0.266 & 0.083 & 3.190 & 0.000 & 0.236 \\
\hline $\begin{array}{l}\text { Knowledge management } \\
\text { performance }\end{array}$ & $\longrightarrow$ Organisational & 0.294 & 0.078 & 3.750 & 0.000 & 0.285 \\
\hline $\begin{array}{l}\text { Organisational innovation } \\
\text { performance }\end{array}$ & $\longrightarrow$ Organisational & 0.212 & 0.057 & 3.650 & 0.000 & 0.231 \\
\hline Human resource practices & $\longrightarrow$ HRM7 & 0.937 & 0.063 & 14.709 & 0.000 & 0.844 \\
\hline Human resource practices & $\longrightarrow$ HRM9 & 0.921 & 0.064 & 14.188 & 0.000 & 0.820 \\
\hline Human resource practices & $\longrightarrow$ HRM12 & 1.000 & & & 0.000 & 0.876 \\
\hline Organisational culture & $\longrightarrow \mathrm{OC} 1$ & 0.981 & 0.084 & 11.580 & 0.000 & 0.855 \\
\hline Organisational culture & $\longrightarrow \mathrm{OC} 2$ & 1.048 & 0.086 & 11.993 & 0.000 & 0.903 \\
\hline Organisational culture & $\longrightarrow \mathrm{OC} 3$ & 1.000 & & & 0.000 & 0.719 \\
\hline Knowledge management & $\longrightarrow \mathrm{KM} 2$ & 0.986 & 0.044 & 21.844 & 0.000 & 0.919 \\
\hline Knowledge management & $\longrightarrow \mathrm{KM} 3$ & 0.959 & 0.039 & 23.940 & 0.000 & 0.949 \\
\hline Knowledge management & $\longrightarrow \mathrm{KM} 4$ & 1.000 & & & 0.000 & 0.908 \\
\hline Organisational innovation & $\longrightarrow \mathrm{OI} 2$ & 0.778 & 0.599 & 12.876 & 0.000 & 0.802 \\
\hline Organisational innovation & $\longrightarrow \mathrm{OI} 3$ & 0.917 & 0.084 & 10.765 & 0.000 & 0.694 \\
\hline Organisational innovation & $\longrightarrow \mathrm{OI} 5$ & 1.000 & & & 0.000 & 0.889 \\
\hline Organisational performance & $\longrightarrow \mathrm{OP} 2$ & 0.934 & 0.042 & 21.745 & 0.000 & 0.885 \\
\hline
\end{tabular}




$\begin{array}{llllll}\text { Organisational performance } & \longrightarrow \mathrm{OP} 3 & 1.000 & & 0.000 & 0.965 \\ \text { Organisational performance } & \longrightarrow \mathrm{OP} 4 & 0.945 & 0.049 & 18.767 & 0.000\end{array}$

Notes: Goodness-of-fit statistics of the model: $x^{2} 203=168.801, p=0.000$; degrees of freedom $(\mathrm{df})=82$; goodness of fit index $(\mathrm{GFI})=0.91$; adjusted goodness-of-fit index $(\mathrm{AGFI})=0.87$; root mean square error of approximation $(\mathrm{RMSEA})=0.07$; comparative-fit-index $(\mathrm{CFI})=$ 0.96 ; incremental fit index $(\mathrm{IFI})=0.96$.

\section{Discussion}

Based on the above mentioned, the first to the third hypotheses have been approved as there is a moral positive relationship among human resource management practices, knowledge management, organisational innovation, and organisational culture. The effect was significant, indicating that Saudi Arabia organisations, which invest in specific types of good human resource management practices, achieve high levels of knowledge, innovation, and the adoption of good organisational culture. Human resource management practices, in particular, have a positive effect on knowledge management, organisational innovation, and organisational culture in those organisations, which involve the use of work teams, performance-based rewards, intensive training, internal communication, the availability of internal job opportunities, and finally a clear job description. The results concluded are inconsistent with those presented in previous experimental studies, such as (Yahya and Goh, (2002) that tested the relationship among four human resource management practices with five fields of knowledge in various kinds of organisations. The results of the research indicated that human resources management is important in knowledge and a positive relationship among the dimensions of knowledge management, training, performance evaluation, recompense and rewards practices.

The fourth and fifth hypotheses have been accepted, which indicates that there is a positive relationship among organisational culture, knowledge management, and organisational innovation. This means that organisations depending on the organisational characteristics that constitute innovation and establish organisational knowledge construct contributing to the creation of new knowledge. Knowledge management initiatives are then more able to promote them. Through a review of previous studies, it is shown that there are few studies conducting a research on these relationships. This is due to the uncertainty surround those dimensions.

The sixth, seventh, and eighth hypotheses have been accepted. This confirms that mediator variables are positively and significantly related, such as organisational culture positively affect knowledge management. Knowledge management, as well, affects organisational innovation, which indicates that Saudi organisations, under study, are able through supporting human resource management practices to promote knowledge management, organisational innovation, and organisational culture. It also indicates that the organisations under study, which construct specific and unusual capacity, will gain a competitive advantage and achieve an increase in the level of performance. Presenting a compound model, associating Porter framework of competitive advantage and organisational culture of the company, Spanos and Lioukas (2001) concluded similar results.

\section{Conclusion}

Despite the fact that cannot be denied that the business management has achieved a lot of progress, there is still some uncertainty about the concepts of knowledge management, organizational innovation, and the relationship between them. Sometimes we find that these concepts are closely related to each other, which lead to overlap each other. The most important thing in the field of human resource management practices that the published studies were not clear enough about the mechanisms though which human resource management practices can impact on performance.

The current study has made an attempt to clarify each of these organizational concepts, which can act as a supportive aspect to achieve a continuous competitive advantage in an era of a rapid organizational change. To achieve this goal, a conceptual framework has been proposed its value lies in the reflection of the factors and their relationships. A lot of researchers in the field of human resources management did not give enough attention to these relationships. The proposed framework represents a complete model that tries to contribute to the literature through exploring the connections and relationships among human resource management practices, knowledge management, organizational innovation, organizational culture, and organizational performance.

The human resource management system proposed in this study suggests a clear image of some important variables that can affect the managers' performance of human resources management and in the way they think about human resource management practices. Knowledge management and organizational innovation play unique roles to emphasize that the traditional focus on personnel management has been amended to become the innovation management and knowledge management (Coates, 2001; Lengnictk-Hall \& Lengnick-Hall, 2003). 
Eventually, it could be argued that the main contributions to the current study are in:

A. The experimental testing of a new synthetic model, which identifies the important mediator factors, required for the relationship of human resource management practices to organizational performance.

B. The value of the human element in knowledge management, organizational innovation, and organizational culture is explored. In spite of previous attempts to study these relations, there is no integrated model that describes tests and reveals these relationships together.

C. Human resources management model characterizes the proposed concepts that can affect in human resources management, with more emphasis on innovation, knowledge, and organizational culture.

D. The results of the model used provided evidences supporting the previous identified hypothesis. Human resource management practices represent a high degree of skill among individuals, and create the motivation for them to be ready to create and share and explore these intangible assets. This type of workforce can enhance the creation of a good knowledge base. Organizational knowledge base cannot surely survive or grow effectively on its own; however, that can be supported and maintained through the processes of accumulation, participation and the use of this knowledge assets across the organization .These complementary effects of knowledge management and organizational innovation processes effectively generate a rare value of capacities, which is a source of competitive advantage enable them to improve organizational performance.

\section{Managerial Implications}

The results of this research enhance those ones of some previous studies, especially studies that has proposed that there is a positive relationship among organisational innovation, organisational culture, knowledge management capabilities, and organisational performance, such as Garc1'a-Morales, Llorens-Montes, and Verdu'-Jover, (2006). In fact, the presence of an appropriate level of investment in sophisticated technology and the endeavor to adopt it also helps in the exploration of knowledge and knowledge storage, distribution and dissemination of knowledge (Tidd \& Trewhella, 2002). Depending on technological learning and knowledge management is a driving force for organisational innovation, and thus has a positive effect on the efficiency of the organisational operating systems (Real, Leal \& Rolda'n, 2006). It is obvious, from the preceding, that the present study clearly contributed in a good understanding of the causal relationship among organisational innovation and organisational culture, knowledge management. Thus, it may be considered of great value to the organisations under study. The administrative effects of the current study can be displayed as follows:

A. Organisational culture, in the companies under study, will greatly affect in knowledge management. This is in line with the results concluded by Khalil, Claudio, and Seliem, (2006); Chang and Lee (2007). Organisational culture will, moreover, affect the organisational innovation and knowledge management, which means that the organisational culture have an significant part in the organisation. In this aspect, Claudette (2003) emphasized that knowledge management positively related to both organisational innovation, and competitive advantages. The current research has confirmed that the organisational culture has a positive relation to knowledge management and organisational innovation as well as it affects the organisational growth and stratigic advantage. Thus, it can be said that the results of the present research demonstrates the value of the results of some other researches (lles \& Yolles 2002; Claudelle, 2003; Bercovitz \& Feldma, 2007).

B. The theoretical models and experimental results indicate that the relationships among organisational culture, knowledge management, and organisational innovation are positive relationships in big Saudi companies. This shows that the aspects of intensive knowledge in those organisations under study are suitable for the execution of knowledge management activities. Therefore, they can be used as a theoretical basis of future discussions about the relations of organisational culture and organisational innovation.

\section{Limitations and Future Research}

Finally, though the experimental results of the current research mainly supports the current model, there are some restrictions that must be taken into account: I) As long as the experimental data of the study is obtained individually (from individuals), there may be some sort of bias; II) The data has been clustered from the organisations in the Kingdom of Saudi Arabia, so the attributes of companies examined may be varied from those in other areas or countries. Consequently, the results of the current study do not necessarily represent the overall issue. The results may, in any case, provide an initial reference of the organisations that are located in other regions or other countries. They are similar to their environment with those in the Kingdom.

The research aims to identify some of the elements playing their own part of mediator between human resource management practices and organisational performance. Therefore, it is entirely logical that the study is not enough to provide a comprehensive image of this subject. Therefore, future studies might benefit from the 
process of integrating these factors. They also need to integrate other factors to develop a new model of human resource management practices such as organisational learning and organisational capacities.

\section{Refrences}

Alavi, M., \& Leidner, D. E. (2001). Review: Knowledge Management and Knowledge Management Systems: Conceptual Foundations and Research Issues. MIS Quarterly, 25(1), 107-136. http://dx.doi.org/10.2307/3250961

Al-Kibsi, G., Benkert, C., \& Schubert, J. (2007). Getting labor policy to work in the Gulf. The McKinsey Quarterly. Retrieved from http://www.mckinseyquarterly.com/Getting_labor_policy_to_work_in_the_Gulf_1930

Alvesson, M., \& Berg, P. O. (1992). Corporate Culture and Organisational Symbolism. Berlin: Walter de Gruyter. http://dx.doi.org/10.1515/9783110136074

Avermaete, T., Viaene, J., Morgam, E. J., \& Crawford, N. (2003). Determinants of Innovation in Small Food Firms. European Journal of Innovation Management, 6(1), 8-17. http://dx.doi.org/10.1108/14601060310459163

Barney, J. B. (1986). Organisational Culture: Can It be a Source of Sustained Competitive Advantage? Academy of Management Review, 11(3), 656-665.

Bercovitz, J., \& Feldma, M. (2007). Fishing Upstream: Firm Innovation Strategy and University Research Alliances. Research Policy, 36(5), 930-948. http://dx.doi.org/10.1016/j.respol.2007.03.002

Bogner, W. C., \& Bansal, P. (2007). Knowledge management as the basis of sustained high performance. Journal of Management Studies, 44(1), 165-88. http://dx.doi.org/10.1111/j.1467-6486.2007.00667.x

Bowen, D., Galang, C., \& Pillai, R. (2002). The role of human resource management: an exploratory study of cross-country variance. Human Resource Management, 41(1), 103-2. http://dx.doi.org/10.1002/hrm.10022

Brewster, C. (2007). HRM: the comparative dimension. In Storey, J. (Ed.), Human Resource Management: A Critical Text. Thomson, London.

Buchowicz, B. (1990). Cultural transition and attitude change. Journal of General Management, 15(4), 45-55.

Bunch, K. J. (2007). Training failure as a consequence of organisational culture. Human Resource Development Review, 6(2), 142-63. http://dx.doi.org/10.1177/1534484307299273

Buono, A. F. (2005). Mergers and acquisitions: managing culture and human resources. Administrative Science Quarterly, 50(4), 647-50.

Byrne, B. (2001). Structural equation modeling with AMOS. New Jersey, USA: Lawrence Erlbaum Associate.

Calori, R., \& Sarnin, P. (1991). Corporate culture and economic performance: a French study. Organisation Studies, 12(1), 49-74. http://dx.doi.org/10.1177/017084069101200104

Carrillo, P., Robinson, H., Ahmed, A. G., \& Anumba, C. (2004). Knowledge management in UK construction: strategies, resources and barriers. Project Management Journal, 35, 46-56. http://dx.doi.org/10.1002/ert.20173

Cawood, S. (2008). Company culture: the intangible pathway to profitability. Employment Relations Today, 34(4), 27-35.

Chalhoub, S. M. (2010). Innovation Management and though Leadership-A Cultural Requirement in a Global Competitive Environment. The Journal of American of Business, 16(1), 240-245.

Chang L., Lee, S., \& Kang, I. (2005). KMPI: measuring knowledge management performance. Information and Management, 42(3), 469-82. http://dx.doi.org/10.1016/j.im.2004.02.003

Chang, S., \& Lee, M. (2007). The Effects of Organisational Culture and Knowledge Management Mechanisms on Organisational Innovation: An Empirical Study in Taiwan. The Business Review, 7(1), 295-301.

Check-Teck, F. (1992). Culture, productivity and structure. Organisation Studies, 13(4), 589-609. http://dx.doi.org/10.1177/017084069201300404

Chen, C., \& Huang, J. (2009). Strategic Human Resource Practices and Innovation Performance - The Mediate Role of Knowledge Management Capacity. Journal of Business Research, 62, 104-114. http://dx.doi.org/10. 1016/j.jbusres.2007.11.016

Claudette, C. (2003). Assessing the Influence of Organisational Culture on Knowledge Management Success. 
Unpublished doctoral dissertation. Nova South-Eastern University, Fort Lauderdale, FL.

Coates, J. (2001). The HR implications of emerging business models. Employment Relations Today, 1-7. http://dx.doi.org/10.1002/ert.12

Craig, J., \& Dibrell, C. (2006). The Natural Environment, Innovation, and Firm Performance: A Comparative Study. Family Business Review, 19(4), 275-288. http://dx.doi.org/10.1111/j.1741-6248.2006.00075.x

Damanpour, F. (1991). Organisational innovation: A meta-analysis of effects of determinants and moderators. Academy of Management Journal, 34, 555-590. http://dx.doi.org/10.2307/256406

Damanpour, F., \& Evan, W. M. (1984). Organisational innovation and performance: The problem of organisational lag. Administrative Science Quarterly, 29, 392-409. http://dx.doi.org/10.2307/2393031

De Boer, K., \& Turner, J. (2007). Beyond oil: reappraising the Gulf States. McKinsey Quarterly. Retrieved from http://www.mckinseyquarterly.com/Beyond_oil_Reappraising_the_Gulf_States_1902

De Kok, J., Uhlaner, L., \& Thurik, R. (2006). Professional HRM practices in family owned-managed enterprises. Journal of Small Business Management, 44(3), 441-60. http://dx.doi.org/10.1111/j.1540-627X.2006.00181.x

Delaney, J. T., \& Huselid, M. A. (1996). The impact of human resource management practices on perception of organisational performance. Academy of Management Journal, 39(4), 949-69. http://dx.doi.org/10.2307/256718

Denison, D. R. (1990). Corporate Culture and Organisational Effectiveness. New York, NY: Wiley.

Fornell, C., \& Larker, F. D. (1981). Evaluating structural equation models with unobservable variables and measurement error. Journal of Marketing Research, 18, 39-50. http://dx.doi.org/10.2307/3151312

Francis, D., \& Bessant, J. (2005). Targeting Innovation and Implications for Capability Development: Technovation, 25, 171-183. http://dx.doi.org/10.1016/j.technovation.2004.03.004

Freeman, C., \& Soete, P. (1997). The Economics of Industrial Innovation (3rd ed.). London,

Garc1'a-Morales, V., Llorens-Montes, F., \& Verdu'-Jover, A. (2006). Antecedents and consequences of organisational innovation and organisational learning in entrepreneurship. Industrial Management \& Data Systems, 106, 21-43. http://dx.doi.org/10.1108/02635570610642940

Gloet, M. (2006). Knowledge management and the links to HRM. Management Research News, 29(7), 402-13. http://dx.doi.org/10.1108/01409170610690862

Gold, A., Malhotra, A., \& Segars, A. (2001). Knowledge Management: Organisational Capabilities Perspective. Journal of Management Information Systems, 18(1), 185-214.

Gomez, C. F., \& Rodriguez, J. K. (2001). Teorias de la cultura organizacional. (Theories of organisational culture). Manual de Contabilidad y Auditoria, 115, 111-40.

Gomez-Mejia, L. R., Balkin, D. B., \& Cardy, R. L. (1998). Managing Human Resources. Prentice-Hall, Englewood Cliffs, NJ.

Guest, D., Michie, J., Conway, N., \& Sheeman, M. (2003). Human resource management and corporate performance in UK. British Journal of Industrial Relations, 41(2), 291-314. http://dx.doi.org/10.1111/1467-8543.00273

Gupt, A., \& Singhal, A. (1993). Managing human resources for innovation and creativity. Research Technology Management, 36(3), 41-8.

Hair, J. F. Jr., Anderson, R. E., Tatham, R. L., \& Black, W. C. (1998). Multivariate Data Analysis (5th ed.). Upper Saddle River, NJ: Prentice Hall.

Hanvanich, S., Sivakumar, K., Tomas, G., \& Hult, M. (2006). The relationship of learning and memory with organisational performance: the moderating role of turbulence. Journal of the Academy of Marketing Science, 34(4), 600-12. http://dx.doi.org/10.1177/0092070306287327

Hewitt-Dundas, N. (2006). Resource and Capability Constraints to Innovation in Small and Large Plants. Small Business Economics, 26, 257-277. http://dx.doi.org/10.1007/s11187-005-2140-3

Hsueh, L., \& Tu, Y. (2004). Innovation and the Operational Performance of Newly Established Small and Medium Enterprises in Taiwan. Small Business Economics, 23, 99-113. http://dx.doi.org/10.1023/B:SBEJ.0000027663.84972.ac 
Huselid, M. A., Jackson, S. E., \& Schuler, R. S. (1997). Technical and strategic human resource management effectiveness as determinants of firm performance. Academy of Management Journal, 40(1), 171-88. http://dx.doi.org/10.2307/257025

Iles, P., \& Yolles, M. (2002). International Joint Ventures, HRM and Viable Knowledge Migration. The International Journal of Human Resource Management, 13(4), 624-641. http://dx.doi.org/10.1080/0958519021 0125633

Irma Becerra, F., \& Rajiv, S. (2001). Organisational Knowledge Management: A Contingency Perspective. Journal of Management Information Systems, 18(1), 23-55.

Jiménez-Jiménez, D., \& Sanz-Valle, R. (2005). Innovation and Human Resource Management Fit: an Empirical Study. International Journal of Manpower, 26(4), 364-381. http://dx.doi.org/10.1108/01437720510609555

Khalil, O., Claudio, A., \& Seliem, A. (2006). Knowledge Management: The Case of the Acushnet Company. Advanced Management Journal, 71(3), 34-45.

Khatri, N., Wells, J., McKune, J., \& Brewer, M. (2006). Strategic human resource management issues in hospitals: a study of a university and a community hospital. Hospital Topics, 84(4), 9-20. http://dx.doi.org/10.3200/HTPS.84.4.9-20

Kotter, J. P., \& Heskett, J. L. (1992). Corporate Culture and Performance. New York: The Free Press.

Kucza, T. (2001). Knowledge Management Process Model. Espoo 2001. Technical Research Centre of Finland. VTT Publications.

Lee, Y. C., \& Lee, S. K. (2007). Capability, processes, and performance of knowledge management: a structural approach. Human Factors and Ergonomics in Manufacturing, 17(1), 21-41. http://dx.doi.org/10.1002/hfm.20065

Lengnick-Hall, M., \& Lengnick-Hall, C. (2003). Human Resource Management in the Knowledge Economy. San Francisco, CA: Berrett-Koehler.

Li, Y., Zhao, Y. B., \& Liu, Y. (2006). The Relationship between HRM Technology Innovation and Performance in China: International Journal of Manpower, 27(2), 679-697. http://dx.doi.org/10.1108/01437720610708284

Liao, S., Fei, W., \& Chen, C. (2007). Knowledge Sharing, Knowledge Absorptive Capacity, and Innovation Capability: An Empirical Study in Taiwan Knowledge Intensive Industries. Journal of Information Science, 33(3), 1-20. http://dx.doi.org/10.1177/0165551506070739

Lim, B. (1995). Examining the organisational culture and organisational performance link. Leadership \& Organisation Development Journal, 16, 16-21. http://dx.doi.org/10.1108/01437739510088491

Lin, C. H., \& Tseng, S. M. (2005). Bridging the Implementation gaps in the knowledge management system for enhancing corporate perfor- mance. Expert Systems with Applications, 29(1), 163-173. http://dx.doi.org/10. 1016/j.eswa.2005.01.015

Ling, T. C., \& Nasurdin, A. M. (2010). Human Resource Management Practices and Organisational Innovation: An Empirical Study in Malaysia. The Journal of Applied Business Research, 26(4), 105-115.

Lord, R., \& Farrington, P. (2006). Age-related differences in the motivation of knowledge workers. Engineering Management Journal, 18, 20-7.

McDermott, R., \& O‘Dell, C. (2001). Overcoming cultural barriers to sharing knowledge. Journal of Knowledge Management, 5(1), 76-85. http://dx.doi.org/10.1108/13673270110384428

Mellahi, K., \& Wood, G. (2001). Human resource management in Saudi Arabia. In Budhwar, P. S., \& Debrah, Y. A. (Eds.), Human Resource Management in Developing Countries. London: Routledge.

Michie, J., \& Sheehan, M. (2005). Business strategy, human resources, labor market flexibility, and competitive advantage. International Journal of HRM, 16(3), 445-64.

Moneva, J. M., Rivera-Lirio, J. M., \& Muñoz-Torres, M. J. (2007). The corporate stakeholder commitment and social and financial performance. Industrial Management \& Data Systems, 107(1), 84-102. http://dx.doi.org/10. 1108/02635570710719070

Nielsen, A. A. (2006). Understanding dynamic capabilities through knowledge management. Journal of Knowledge Management, 10(4), 59-71. http://dx.doi.org/10.1108/13673270610679363 
Nonaka, I. (1994). A Dynamic Theory of Organisational Knowledge Creation. Organisational Science, 5(1), 14-37. http://dx.doi.org/10.1287/orsc.5.1.14

Nunnally, J. C. (1978). Psychometric Theory. New York, NY: McGraw-Hill,

Oltra, V. (2005). Knowledge management effectiveness factors: the role of HRM. Journal of Knowledge Management, 9(4), 70-86. http://dx.doi.org/10.1108/13673270510610341

Parker, M. (2000). Organisational Culture and Identity. London: Sage Publishing Ltd. http://dx.doi.org/10.1038/35008023

Prajogo, D. I. (2007). The relationship between competitive strategies and product quality. Industrial Management \& Data Systems, 107(1), 69-83. http://dx.doi.org/10.1108/02635570710719061

Real, J., Leal, A., \& Rolda'n, J. (2006). Information technology as a determinant of organisational learning and technological distinctive competencies. Industrial Marketing Management, 35, 505-21. http://dx.doi.org/10.1016/ j.indmarman.2005.05.004

Robbins, P., \& Judge, A. (2009). Organisational Behavior. New Jersey: Pearson Education, Inc.

Robertson, M., \& Hammersley, G. M. (2000). Knowledge management practices within a knowledge-intensive firm: the significance of the people management dimension. Journal of European Industrial Training, 24(2), 241-53. http://dx.doi.org/10.1108/03090590010321205

Rodriguez, J. K. (2001). Dilemas de la Cultura Organizacional: Una Visio'n Introductoria. (Dilemmas in organisational culture: an introductory look). Revista Empreciencias, 2(3), 33-42.

Rogers, E. M. (1995). Diffusion of innovations (4th ed.). New York: Free Press.

Rokkan, A. I., Heide, J. B., \& Wathne, K. H. (2003). Specific investments in marketing relationships: expropriation and bonding effects. Journal of Marketing Research, 40(2), 210-224. http://dx.doi.org/10.1509/jmkr.40.2.210.19223

Rousseau, D. M. (1990). New hire perceptions of their own and their employer's obligations: a study of psychological contracts. Journal of Organisational Behavior, 11, 389-400. http://dx.doi.org/10.1002/job.4030110506

Sarvary, M. (1999). Knowledge management and competition in the consulting industry. California Management Review, 41, 95-107. http://dx.doi.org/10.2307/41165988

Scarbrough, H. (2003). Knowledge management, HRM and the innovation process. International Journal of Manpower, 24(5), 501-16. http://dx.doi.org/10.1108/01437720310491053

Scarbrough, H., \& Carter, C. (2000). Investigating Knowledge Management. London: CIPD.

Schein, E. H. (1984). Coming to a New Awareness of Organisational Culture. Sloan Management Review, 25(2), 3-16.

Schein, E. H. (2004). Organisational Culture and Leadership. Jossey-Bass, a Wiley.

Schu, R. S., \& Jackson, S. E. (1987). Linking competitive strategies with human resource management practice. The Academy of Management Executive, 1(3), 207-19. http://dx.doi.org/10.5465/AME.1987.4275740

Schultz, M. (1994). On Studying Organisational Cultures: Diagnosis and Understanding. Berlin: alter de Gruyter \& Co.

Sels, L., De Winne, S., Maes, J., Delmotte, J., Faems, D., \& Forrier, A. (2006). Unravelling the HRM-performance link: value-creating and cost-increasing effects of small business HRM. Journal of Management Studies, 43(2), 319-42. http://dx.doi.org/10.1111/j.1467-6486.2006.00592.x

Shih, H., \& Chiang, Y. (2005). Strategy alignment between HRM, KM, and corporate development. Information Journal of Manpower, 26(6), 582-603. http://dx.doi.org/10.1108/01437720510625476

Shili, S. (2008). Organisational Culture and Its Themes. International Journal of Business and Management, $3(12), 137-141$.

Siehl, C., \& Martin, J. (1990). Organisational culture: A key to financial performance? In B. Schneider (Ed.), Organisational climate and culture (pp. 241-281). San Francisco: Jossey-Bass.

Soliman, F., \& Spooner, K. (2000). Strategies for implementing knowledge management: role of human resources management. Journal of Knowledge Management, 4(4), 337-45. http://dx.doi.org/10.1108/13673270010379894 
Spanos, Y. E., \& Lioukas, S. (2001). An examination into the causal logic of rent generation: contrasting Porter's competitive strategy framework and the resource-based perspective. Strategic Management Journal, 22(10), 907-934. http://dx.doi.org/10.1002/smj.174

Steer, R. M. (1975). Problems in the measurement of organisational effectiveness. Administrative Science Quarterly, 20(4), 546-58. http://dx.doi.org/10.2307/2392022

Subrmanian, A., \& Nillakanta, S. (1996). Organisation innovativeness: exploring the relationship between organisational determinants of innovation, types of innovations, and measures of organisational performance. Omega, 24(6), 631-47. http://dx.doi.org/10.1016/S0305-0483(96)00031-X

Taylor, S., Levy, O., Boyacigiller, N. A., \& Beechler, S. (2008). Employee commitment in MNCs: impacts of organisational culture, HRM and top management orientations. International Journal of Human Resource Management, 19(4), 501-27. http://dx.doi.org/10.1080/09585190801953491

Thite, M. (2004). Strategic positioning of HRM in knowledge-based organisations. The Learning Organisation, 11(1), 28-44. http://dx.doi.org/10.1108/09696470410515715

Tichy, N., Fombrun, C., \& Deyanna, M. (1982). Strategic human resource management. Sloan Management Review, 23(2), 47-60.

Tidd, J., \& Trewhella, M. (2002). Organisational and technological antecedents for knowledge acquisition and learning. $R \& D$ Management, 27, 359-75. http://dx.doi.org/10.1111/1467-9310.00071

Venkatraman, N., \& Ramanujam, V. (1986). Measurement of business economic performance: an examination of method convergence. Journal of management Development, 13(1), 109-22.

Wallach, E. (1983). Individual and Organisations: The Cultural Match. Training and Development Journal, $37(2), 28-35$.

Wiesner, R., \& McDonald, J. (2001). Bleak house or bright prospect? Human resource management in Australian SMEs. Asia Pacific Journal of Human Resources, 39(2), 28-50. http://dx.doi.org/10.1177/103841110103900203

Wong, W. P., \& Wong, K. Y. (2007). Supply chain performance measurement system using DEA modeling. Industrial Management \& Data Systems, 107(3), 361-81. http://dx.doi.org/10.1108/02635570710734271

Yahya, S., \& Goh, W. (2002). Managing human resources toward achieving knowledge management. Journal of Knowledge Management, 6(5), 457-68. http://dx.doi.org/10.1108/13673270210450414

Zack, M. (1999). Developing a knowledge strategy. California Management Review, 41(3), 125-45. http://dx.doi.org/10.2307/41166000

Zahra, S., Ireland, R., \& Hitt, M. (2000). International Expansion by New Venture Firms: International Diversity, Mode of Market Entry, Technological Learning and Performance. Academy of Management Journal, 43(5), 925-950. http://dx.doi.org/10.2307/1556420

\section{Appendix (A) the list of initial items}

\section{(1) Human Resource Management Practices}

HRM1- Job safety is guaranteed for almost all employees in the organisation.

HRM2- The study and analysis of the positive and negative aspects in the personality of applicant and personal trends are analyzed, as part of the recruitment and selection process.

HRM3- The organisation has specific and clear policies and procedures of recruitment processes.

HRM4- When we work together as a team, there is an urgent necessity for every individual ideas of the team to learn from each other and get to success.

HRM5- Directors always works to keep the communication open with employees.

HRM6- Employees are related to compensation system on different based on skills and extensive knowledge. This also gives the opportunity to earn rewards for achievements.

HRM7- Employees are related to reward system based on the team's performance or the performance of the group, connecting with a part of the salary to performance. $(*)$

HRM8- There is a personal trainer for each worker to whom they can talk individually. 
HRM9- There are opportunities for those workers in this organisation to attend training courses to improve or learning new and multiple skills. $(*)$

HRM10- Employees have opportunities to express opinions taken into account by the management of the organisation when planning changes.

HRM11- Employees have opportunities to receive feedback on their performance.

HRM12- Employees have clear career paths and potential opportunities for promotion within the organisation.

(*)

HRM13- Organisation owns a modern functional description, containing all the duties performed by employees of the organisation.

HRM14- Organisation is committed to achieve industrial and job safety for their employees.

\section{(2) Knowledge Management}

KM1- Researches, in collaboration with universities / research centers, are conducted to explore the future potential and to gain knowledge.

KM2- Employees regularly attend courses and seminars and training programs in order to be permanently updated with new knowledge. $(*)$

KM3- The experience owned by organisation's experts is adopted to contribute to and participate with others within the organisation. $(*)$

KM4- The workers of organisation shall inform each other regularly on the positive experiences and successful working methods. $(*)$

KM5- experts are encouraged to advertise openly about the methods they use in product development.

\section{(3) Organisational Culture}

OC1- The culture of the organisation depends on the division of authority sequence. There are also clear lines of responsibility and authority. $\left.{ }^{*}\right)$

OC2- Working in the organisation is considered structured and systematic. Culture of the organisation is usually based on control and power. $(*)$

OC3- Organisation working environment is to be perfectly suited for innovation and leadership, adventure, challenge, creativeness, and results-oriented. $\left.{ }^{*}\right)$

OC4- Organisation working environment is a supportive environment characterized by extremely reliable, safe and fair, encouraging, open, relations and cooperation oriented.

OC5- Organisation's workers are friendly and are characterized by justice and useful to each other.

\section{(4) Organisational Innovation}

OI1- The environment that contribute to show self-capabilities for the production of useful and new ideas promotes and creates the organisation.

OI2- The organisation spends a lot of time for the production of useful and developed ideas in the field of services. (*)

OI3- The organisation has, during the past five years, developed and implemented many of the modern management methods. $(*)$

OI4- The top executives of the organisation search for solutions to problems in unusual ways through the use of innovative ideas.

OI5- We get a lot of support from our managers if we want to try new ways of doing things. $(*)$

\section{(5) Organisational Performance}

How you would compare the organisational performance of the organisation during the last three years with other organisations in the same field, according to the following: 
OP1- Return on shareholders' equity.

OP2- Net profit. $(*)$

OP3- Market share. $\left(^{*}\right)$

OP4- The value of sales. $(*)$

OP5- The level of improvement in customer satisfaction.

OP6- The development in the field of customer communications.

OP7- The degree of customer retention.

$\left.{ }^{*}\right)$ Elements that have emerged in the final construction of the scale that was used.

\section{Copyrights}

Copyright for this article is retained by the author(s), with first publication rights granted to the journal.

This is an open-access article distributed under the terms and conditions of the Creative Commons Attribution license (http://creativecommons.org/licenses/by/3.0/). 